\title{
Urbanisation as a driver of change
}

\author{
S. Thomas \\ Arup, Cardiff, UK
}

\begin{abstract}
Half the world's population now lives in urban areas. Urbanisation has been a rapid process and virtually all the forecast population growth in coming years will take place in urban areas in less developed countries. Research into urbanisation at Arup has been undertaken as part of an initiative to look at Drivers of Change - an ongoing programme exploring issues most likely to have a major impact upon society. There is clear evidence that urbanisation can play a positive role in social and economic development. By concentrating half the world's population on less than $3 \%$ of its land area, urban settlements give sustainability a better chance. However, cities also draw together many of the world's major environmental problems. It is important to understand the negatives associated with urbanisation and see these in terms of opportunities and chances to do things differently in the future.
\end{abstract}

Keywords: urbanisation, population growth, cities, slums.

\section{Introduction}

Urbanisation is generally defined as the process of growth in the proportion of a country's population living in urban areas. The 20th century witnessed rapid world urbanisation, with the global urban proportion rising from $13 \%$ in 1900 to $49 \%$ in 2005 . In terms of numbers this is a change from $220 \mathrm{M}$ urban dwellers in 1900 to 3.2 bn in 2005 - a 15 -fold increase [1].

This paper looks at what has caused this change and what it may mean to have half the world's population living in urban areas - a proportion that is set to increase.

\subsection{Definitions}

While there is general agreement that urbanisation is growth in the proportion of a country's population living in urban areas, there is less agreement about what 
constitutes an urban area - and there is no common definition of the word "urban". Different criteria and methods are currently used by governments to define urban, as noted in the UN-HABITAT Report State of the World's Cities 2006/7 [2]:

- In 105 countries, urban data are based on administrative criteria, limited to the boundaries of state or provincial capitals, municipalities, or other local jurisdictions. In 83 countries this is the sole method of distinguishing "urban" from "rural".

- In 100 countries, cities are defined by population size or population density, with minimum concentrations ranging broadly from 200 to 50000 inhabitants. In 57 countries this is the sole urban criterion.

- In 25 countries, economic characteristics are specified as significant, though not exclusive, in defining cities - typically the proportion of the labour force employed in non-agricultural activities.

- In 18 countries, the availability of urban infrastructure is counted in their definitions, including the presence of paved streets, water supply systems, sewerage systems, or electric lighting.

- In 25 countries there is no definition of urban at all.

- In six countries, the entire population is regarded as urban.

The terms "urban" and "cities" are often taken to mean the same thing, but it is important to note that not all urban areas are cities. Urban areas include towns and other smaller settlements.

\section{Causes and patterns of urbanisation}

Urbanisation has three components: natural increase, migration, and the reclassification of rural areas as urban or a change in the criteria for "urban". Many consider that migration is the dominant factor, but the main cause today is generally natural increase. The latest comprehensive research effort to separate it from other components of urban growth puts its contribution at about $60 \%$ in the median country. The remaining part of urban growth - roughly $40 \%-$ is a combination of migration and reclassification [3].

The situation in China, where rural to urban migration has recently predominated, is unusual. The prosperity of China's cities is largely a result of economic reform policies with a pro-urban focus. Since the mid-1980s China has pursued an aggressive urbanisation policy as a way to stimulate both rural and urban economic development. The policy aims to absorb the hundreds of millions of farmers who flock to cities as a result of economic reforms and easing of previously strictly enforced "urban residency permits" [2]. It is estimated that in the next two decades, about $12 \mathrm{M}$ people will relocate from rural to urban areas every year, and China is planning to build another 400 new cities with populations averaging 600000 people [4].

In many developing countries, urban areas offer more hope of jobs and better living standards. As well as the "pull" factor of greater opportunity, there are the "push" factors of stagnant rural economies, inequitable land distribution and degraded environments. Migration persists from rural areas without 
unemployment to urban areas showing high unemployment on the basis of expectations of long-term income and substantial increases in living standards.

In some parts of the world, the primary influence on urbanisation is the movement of people uprooted by drought, famine, ethnic conflicts, civil strife, and war. Conflicts and crises in war-torn countries often result in the mass exodus of rural communities to urban areas, where most end up in low-income, poorly-serviced settlements or slums.

\subsection{The rise of the modern city - the first wave of urbanisation}

The modern city arose from major innovations in combustion technology. Industrial cities began to develop in Britain in the 18th century, and in the 200 years between 1750 and 1950, Europe and North America experienced the first demographic transition, the first industrialisation, and the first wave of urbanisation. In the past half-century, the less-developed regions have begun the same transition.

\subsection{The second wave of urbanisation}

A recent United Nations Population Fund (UNFPA) report [3] notes that the huge increases in urban population in poorer countries are part of a "second wave" of demographic, economic, and urban transitions, much bigger and faster than the first. Of the world's urban growth over the next two decades, 95\% will be in less developed countries.

Mortality rates have fallen rapidly and dramatically in most of the lessdeveloped regions, achieving in one or two decades what developed countries accomplished in one or two centuries. Cities in poorer countries will need to build new urban infrastructure more rapidly than cities anywhere during the first wave of urbanisation.

The next few decades will see an unprecedented scale of urban growth in the developing world. This will be particularly notable in Africa and Asia where the urban population will double between 2000 and 2030 - so the accumulated urban growth of these two regions during the whole span of history will be duplicated in a single generation.

India is rapidly industrialising and urbanising. Its population is currently less urbanised than China's (29\% compared to 37\%), and while China's population is forecast to grow by $10 \%$ between 2006 and 2050, the forecast for India is $45 \%$, taking its population to $1.6 \mathrm{bn}$ and making it the most populous country in the world by 2050 .

The UNFPA stresses the importance of three policy initiatives with regard to this forecast growth. First, preparing for an urban future requires, at a minimum, respecting the rights of the poor to the city. Secondly, cities need a longer-term and broader vision of the use of urban space to reduce poverty and promote sustainability. Thirdly, population institutions and specialists should play a key role in supporting community organisations, social movements, governments, and the international community in improving the nature and form of urban 
expansion, and thus enhancing its power to reduce poverty and promote environmental sustainability.

\subsection{Megacities}

In 1800 there were two "million-cities", London and Beijing, and by 1900 there were four, Tokyo and Delhi having reached that status. A century later, the number of "million-cities" had increased to 200, with a further 100 having between $1 \mathrm{M}$ and $10 \mathrm{M}$ inhabitants, and 19 megacities with populations exceeding $10 \mathrm{M}$ [1] (Table 1). Eight more megacities are projected to emerge over the next two decades, making the total 27 by 2025, with 18 of them in developing countries.

Much attention in the past half-century was given to the rise of megacities. Some regard them as the "global urban future" [5], but in 2005 , less than $10 \%$ of the world's urban population lived in megacities, and this proportion is forecast to be about the same $(9.4 \%)$ in 2025 [1]. This means that less than $5 \%$ of the world's total population lives in megacities.

Attention has focused on megacities because they represent an extreme, but there are not as many, nor are they as big, as was forecast. For example, in the 1970s it was projected that by the year 2000 there would be 27 megacities and that the population of Calcutta would be 40-50M and Mexico City $31 \mathrm{M}$ [6]. The reasons for these predictions not materializing are unclear; there is much debate about whether cities have a "natural maximum size", and whether this is an optimum size for urban areas in terms of environmental impact, sustainability, and quality of life.

\subsection{A brief history of urban areas [4]}

Archaeology indicates that the first complex urban societies originated in Sumeria, southern Mesopotamia (today's southern Iraq), about 3500 BCE. Within a few hundred years, dozens of cities including Uruk and Ur emerged there. They owed their sustenance to irrigation-based farming systems, which seem to have originated about $6000 \mathrm{BCE}$. These early cities had a substantial environmental impact, coming to depend on ever more resources from an ever larger hinterland as they grew. The eventual demise of Ur and other Sumerian cities was linked to use of irrigation water that led to the salinisation of farmland, with catastrophic consequences for food supply. Hostile invasions also played a role in their downfall, with jealousies and wars over wealth.

The story of Rome starts around $750 \mathrm{BCE}$, when it was a small village. Rome thrived because it straddled a trade route and was on the banks of a river. It grew to a population of some $1.2 \mathrm{M}$ in about 1000 years, becoming, the first "million city" around AD 250. To meet the needs of the city, Rome had to keep improving its water supply system, and nine separate aqueducts were built as demand in the city grew.

Between AD 500 and 1000, Rome's contraction to a town of just 30000 people occurred. There were many reasons for its decline and fall - invasions, punitive taxes in the colonies, civil wars, corruption, famines, plagues - but there 
is little doubt that environmental factors like deforestation, soil erosion, and salinisation also played a major part in the drawn-out demise of the Roman Empire.

Table 1: $\quad$ Rankings and populations of megacities in 2007 and 2025 [2].

\begin{tabular}{|c|c|c|c|c|c|}
\hline \multicolumn{6}{|l|}{2007} \\
\hline Rank & City & Population & Rank & City & Populati \\
\hline 1 & Tokyo & $35.7 \mathrm{M}$ & 11 & $\begin{array}{l}\text { Los Angeles-Long } \\
\text { Beach-Santa Ana }\end{array}$ & $12.5 \mathrm{M}$ \\
\hline 2 & $\begin{array}{l}\text { New York- } \\
\text { Newark }\end{array}$ & $19.0 \mathrm{M}$ & 12 & Karachi & $12.1 \mathrm{M}$ \\
\hline 3 & Ciudad de México & $19.0 \mathrm{M}$ & 13 & Al-Qahirah & $11.9 \mathrm{M}$ \\
\hline 4 & Mumbai & $19.0 \mathrm{M}$ & 14 & Rio de Janeiro & $11.7 \mathrm{M}$ \\
\hline 5 & São Paulo & $18.8 \mathrm{M}$ & 15 & Osaka-Kobe & $11.3 \mathrm{M}$ \\
\hline 6 & Delhi & $15.9 \mathrm{M}$ & 16 & Beijing & $11.1 \mathrm{M}$ \\
\hline 7 & Shanghai & $15.0 \mathrm{M}$ & 17 & Manila & $11.1 \mathrm{M}$ \\
\hline 8 & Kolkata & $14.8 \mathrm{M}$ & 18 & Moskva & $10.5 \mathrm{M}$ \\
\hline 9 & Dhaka & $13.5 \mathrm{M}$ & 19 & Istanbul & $10.1 \mathrm{M}$ \\
\hline 10 & Buenos Aires & $12.8 \mathrm{M}$ & & & \\
\hline
\end{tabular}

\begin{tabular}{|c|c|c|c|c|c|}
\hline \multicolumn{6}{|l|}{2025} \\
\hline Rank & City & Populati & Rank & City & Population \\
\hline 1 & Tokyo & $36.4 \mathrm{M}$ & 15 & Beijing & $14.5 \mathrm{M}$ \\
\hline 2 & Mumbai & $26.4 \mathrm{M}$ & 16 & Buenos Aires & $13.8 \mathrm{M}$ \\
\hline 3 & Delhi & $22.5 \mathrm{M}$ & 17 & $\begin{array}{l}\text { Los Angeles-Long } \\
\text { Beach-Santa Ana }\end{array}$ & $13.7 \mathrm{M}$ \\
\hline 4 & Dhaka & $22.0 \mathrm{M}$ & 18 & Rio de Janiero & $13.4 \mathrm{M}$ \\
\hline 5 & São Paulo & $21.4 \mathrm{M}$ & 19 & Jakarta & $12.4 \mathrm{M}$ \\
\hline 6 & Ciudad de México & $21.0 \mathrm{M}$ & 20 & Istanbul & $12.1 \mathrm{M}$ \\
\hline 7 & $\begin{array}{l}\text { New York- } \\
\text { Newark }\end{array}$ & $20.6 \mathrm{M}$ & 21 & Guangzhou & $11.8 \mathrm{M}$ \\
\hline 8 & Kolkata & $20.6 \mathrm{M}$ & 22 & Osaka-Kobe & $11.4 \mathrm{M}$ \\
\hline 9 & Shanghai & $19.4 \mathrm{M}$ & 23 & Moskva & $10.5 \mathrm{M}$ \\
\hline 10 & Karachi & $19.1 \mathrm{M}$ & 24 & Lahore & $10.5 \mathrm{M}$ \\
\hline 11 & Kinshasa & $16.8 \mathrm{M}$ & 25 & Shenzhen & $10.2 \mathrm{M}$ \\
\hline 12 & Lagos & $15.8 \mathrm{M}$ & 26 & Chennai & $10.1 \mathrm{M}$ \\
\hline 13 & Al-Qahirah & $15.6 \mathrm{M}$ & 27 & Paris & $10.0 \mathrm{M}$ \\
\hline 14 & Manila & $14.8 \mathrm{M}$ & & & \\
\hline
\end{tabular}

This brief look at the earlier history of urban areas shows that many of the issues and problems associated with urbanisation today, such as how to provide urban populations with water and with food, are nothing new. The difference now is the scale on which such problems are happening. 


\section{Some topics associated with urbanisation}

\subsection{Urban agriculture}

The development of urban areas was made possible through the concentration of food production to create a surplus, but many cities have now come to depend on highly unsustainable supplies for the bulk of their food.

In many cities, particularly in the developing world, urban agriculture - the practice of growing, raising, processing, and distributing food in and around an urban area - contributes significantly to urban food supply and household food security, particularly among low-income groups [2]. Shanghai is one of the world's fastest growing cities, yet half the 630 000ha administered by the authorities has been set aside for urban agriculture [4].

This can also be a more sustainable way of providing food, by reducing the energy and environmental costs. Cuba has become a world leader, with food production decentralised from large mechanised state farms to urban cultivation systems. Demand for local produce in cities is likely to increase, so future urbanisation is likely to require land to be set aside for food production.

\subsection{Urban areas and the climate}

Urban areas are both subject to, and an increasing component of, regional climate change [7]. Most of the increase of $\mathrm{CO}_{2}$ in the atmosphere is attributable to energy consumption in the world's cities. With $\mathrm{CO}_{2}$ emissions increasing to record highs, global warming will soon reach the point of no return; 11 of the last 12 years (1995 - 2006) rank among the 12 warmest years in the instrumental record of global surface temperature (since 1850) [8].

Rising sea levels due to global warming will take a heavy toll on cities because many are located on low ground close to the sea; $40 \%$ of the world's population lives within $65 \mathrm{~km}$ ( 40 miles) of the sea. Many non-coastal cities would also face problems of flooding as they are beside rivers or in foothills of mountains in locations vulnerable to intense rainfall or snowmelt.

Large cities can also disturb weather patterns, creating a micro-climate called an urban heat island (UHI). Urban areas can have UHIs that may be up to $5-6^{\circ} \mathrm{C}$ warmer than the surrounding countryside. The impact of rising temperatures is likely to exacerbate the urban heat island effect, and the associated health impacts. The heat wave in Europe in August 2003 was considered to be responsible for some 35000 deaths [9].

\subsection{Employment and globalisation}

Employment is a primary reason for immigration. In 2005 there were more than $191 \mathrm{M}$ international migrants in the world, the highest number ever, equating to one person in 35 . The country that attracts the most people from abroad is the United States (35M), followed by Russia (13.3M) and Germany (7.3M). China sees the most people leave, followed by India and the Philippines. 
Increasingly, urban growth is influenced by continued global economic integration. It has been predicted [10] that the 21 st century will see a resurgence of economically powerful global cities in Asia. The globalisation process has had a very uneven impact across the world, with both positive and negative impacts on cities. The positive include rising prosperity, the enduring importance of urban cores, and increased democracy, while the negative consist of sharpening imbalances, increased social disorder, and greater citizen expectations.

\subsection{The urbanisation of poverty}

The link between urbanisation and socioeconomic development is rarely disputed - but in many cities of both the developed and the developing world, economic growth has not resulted in prosperity for all. Instead, intra-city inequalities have risen as the gap between rich and poor has widened. UNHABITAT states [2] that many cities are now effectively two cities within one one part of the population has all the benefits of urban living, but the other, the poor, are in slums and squatter settlements.

Sub-Saharan African countries have some of the world's highest levels of urban poverty, extending to more than $50 \%$ of the urban populations in Chad, Niger, and Sierra Leone. In Asia, India has the highest urban poverty levels, at $30 \%$ [2]. The high costs of items such as transport, health, education, and water, coupled with poor living conditions including inadequate housing and poor access to basic services, adversely impact the ability of the urban poor to rise out of poverty. The Executive Director of the UN Human Settlements Programme, Anna Tibaijuka, has described the urbanisation of poverty as the "weakest link" in sustainable development [11].

\subsection{Urbanisation and the growth of slums}

A slum household is defined by the UN [2] as a group of individuals living under the same roof in an urban area who lack one or more of five conditions, given below with some current statistics.

(1) Durable housing: a house is considered "durable" if it is built on a nonhazardous location and has a structure permanent and adequate enough to protect its inhabitants from the extremes of climatic conditions, such as rain, heat, cold and humidity $-18 \%$ of all urban housing units are non-permanent structures.

(2) Sufficient living area: a house is considered to provide sufficient living area for the household members if not more than three people share the same room - some $20 \%$ of the developing world's urban population live in houses that lack sufficient living area.

(3) Access to improved water: a household is considered to have access to improved water supply if it has a sufficient amount of water for family use, at an affordable price, and available to household members without being subject to extreme effort, especially on the part of women and children - only two-thirds of the world's urban population gets water from a tap.

(4) Access to sanitation: a household is considered to have adequate access to sanitation if an excreta disposal system, either in the form of a private toilet or a 
public toilet shared with a reasonable number of people, is available to household members - over $25 \%$ of the developing world's urban population $560 \mathrm{M}$ city residents - lack adequate sanitation.

(5) Secure tenure: the right of all individuals and groups to effective protection against forced evictions. People have secure tenure when there is evidence of documentation that can be used as proof of secure tenure status or when there is either de facto or perceived protection against forced evictions non-empirical evidence from UN-HABITAT indicates that $30-50 \%$ of urban residents in the developing world have no legal document such as title deed or a contract to prove tenure security, and without such documents, forced urban evictions can result.

The problems of poor-quality housing are exacerbated by the fact that poor people in developing countries are particularly vulnerable to disasters as they are more likely to live on dangerous floodplains, river banks, steep slopes and reclaimed land, and their housing is less likely to survive a major disaster. For example, an investigation into the 2003 earthquake in Bam, Iran, found that most of the 40,000 people killed lived in housing that was built in the traditional mud-brick style without the necessary supportive structures to withstand tremors [2].

Given the forecast growth in urbanisation in less developed countries, problems such as non-durable housing and lack of security of tenure are likely to worsen.

\subsection{Governance}

Urbanisation offers significant opportunities to reduce poverty and gender inequality, as well as promote sustainable development. For humankind to benefit from the urban transition, leaders must first accept it as both inevitable and important for development. However, three-quarters of all governments have reported $[12,13]$ that they are dissatisfied with the spatial distribution of their populations, and almost three-quarters of developing countries have enacted policies to reduce the flow of persons moving to urban areas.

Rather than attempt to prevent urban expansion, planners must examine the available policy options for addressing it and building on its possibilities. Examples of the differences made in some cities by mayors in recent years highlight some of the possibilities. The potential for strong political leadership can come with urbanisation, and such leadership can in turn strengthen a city's position. In Bogota, a series of co-ordinated actions by successive mayors has turned a once-violent, car-dominated city facing dramatic levels of in-migration from its rural hinterlands into a calm and well-managed city - with an efficient rapid transit bus system, a network of cycleways, public parks, and urban plazas that have changed life for the city's inhabitants, improving its quality and reducing crime.

The absence of effective governance structures results in a lack of planning, development control, and infrastructure provision. In an increasingly urbanised world, effective planning policies are needed for both urban and rural areas. 


\section{Conclusion}

Population and urban forecasts have not always materialised, and it is important to recognise that forecasts are just that - forecasts. The population in 2050 may not reach over $9 \mathrm{bn}$ people, and it may be that not as many as $70 \%$ of the world's population will be living in urban areas. However, what does seem to be beyond doubt is that for the foreseeable future, the urban population is set to increase.

There is clear evidence that urbanisation can play a positive role in social and economic development. Historically, the statistical association between urbanisation and economic growth has been strong. Today, cities generally have greater potential than rural areas for reducing poverty. There is growing recognition that urban settlements and demographic concentration give sustainability a better chance - concentrating half the world's population on less than $3 \%$ of its land area [3].

However, in many cities in both the developed and the developing world, economic growth has not resulted in prosperity for all. Instead, intra-city inequalities have risen as the gap between rich and poor has widened. Cities also draw together many of the world's major environmental problems: population growth, pollution, resource degradation, and waste generation.

Urbanisation may be seen as inevitable - but it can be positive. While some statistics associated with it are depressing, it is important to understand the negatives and to see these in terms of opportunities and chances to do things differently in the future. The potential benefits far outweigh the disadvantages.

Long-term planning for urban areas needs to be looked at holistically. Any town or city has many components or "urban ingredients", and there are complex relationships between them: the facilities, in terms of physical infrastructure; the systems and utilities that an urban area needs to function; the services that urban residents require; and the attributes that it is desirable for an urban area to have. Considering, comprehending, and balancing all these urban ingredients requires the input of many disciplines, as well as respect for the local environment, both geographically and culturally, and its people.

\section{Acknowledgement}

The author is the lead researcher on urbanisation for Arup's Drivers of Change programme.

\section{References}

[1] United Nations Department Of Economic And Social Affairs: Population Division. World urbanisation prospects: The 2007 revision. UNDESA, 2007.

[2] UN-habitat. State of the world's cities 2006/7. UN-HABITAT, 2006.

[3] United Nations Population Fund. State of world population report 2007: Unleashing the potential of urban growth. UNFPA, 2007. 
[4] Girardet, H. Cities people planet: Liveable cities for a sustainable world. Wiley-Academy, 2004.

[5] Planet Earth: Earth Sciences For Society. Megacities - our global urban future. Earth Sciences for Society Foundation, 2005.

[6] International Institute For Environment And Development. Human settlements discussion paper series. Theme: Urban Change-4. The transition to a predominantly urban world and its underpinnings, by David Satterthwaite. IIED, 2007.

[7] Wilby, RL. A review of climate change impacts on the built environment. Built Environment (Special Edition) 27 July 2006 (Climate Change Unit, Environment Agency UK).

[8] Intergovernmental Panel On Climate Change, 2007: Summary for policymakers. In: Climate change 2007: The physical science basis. Contribution of Working Group I to the Fourth Assessment Report. CUP, 2007.

[9] "European heatwave caused 35,000 deaths". New Scientist, 10 October 2003

[10] Hall, P and Pfeiffer, U. Urban Future 2: A global agenda for twenty-first century cities. Spon, 2000.

[11] “Champion of the poor". Planning Magazine, 22 June 2007, page 4.

[12] Jenkins, P, et al. Planning and housing in the rapidly urbanising world. Routledge, 2006.

[13] United Nations Department Of Economic And Social Affairs: Population Division. World urbanisation prospects: The 2007 revision. Fact sheet 9: Government views and policies. UNDESA, 2007. 